\title{
Tomaž Sajovic
}

\section{UNIČEVANJE MIŠLJENJA}

\section{POVZETEK}

Današnjo neoliberalno avtoritarno družbo obvladuje - če uporabimo besednjak Slavoja Žižka iz besedila Leninova izbira (2010) - nezapisani Denkverbot, »prepoved « kritičnega mišljenja, ki jo zgodovinsko ponazarja znamenita izjava angleške ministrske predsednice Margaret Thatcher: „Neoliberalizem nima alternative. Neoliberalna ekonomska in družbena kontrarevolucija se je v 60. letih spočela na Oddelku za ekonomijo Univerze v Chicagu, njen najpomembnejši zagovornik pa je bil ameriški ekonomist in Nobelov nagrajenec za ekonomijo Milton Friedman. Friedmanov program je bil skrajno konservativen: "Prvič, vlade morajo odpraviti vsa določila in regulativo, ki preprečuje kopičenje dobička. Drugič, odprodati morajo vse premoženje, ki ga imajo v lasti in bi ga korporacije lahko vodile z. dobičkom. In tretjič, financiranje socialnih programov morajo dramatično zmanjšati. To popolnoma nečloveško ideologijo, ki se je »točno ujemala z interesi velikih multinacionalk«, je Friedman »skrbno « skril v akademizacijski »jezik matematike in znanosti in jo s tem »preoblikoval v nepristransko ekonomsko znanost. Neoliberalno urejanje gospodarstva tako naj ne bilo več stvar subjektivnih človeških odločitev, ampak»le« še izpolnjevanje znanstveno ugotovljenih naravnih zakonov. $O$ njem zato naj ne bi bilo več mogoče »dvomiti« niti naj ne bi bilo več »smisla o njem kritično razmišljati. Predpostavka je, da neoliberalna ekonomska ideologija lahko parazitira na znanosti le zato, ker so $v$ neoliberalizmu tudi znanosti same postale »ideologija«. Švicarsko-kanadski sociolog in filozof Michel Freitag (1935-2009) jih je v svoji knjigi Brodolom univerze (1995, v slovenskem prevodu 2010) imenoval tehnoznanosti: "Znanost se ne ukvarja več s spoznavanjem sveta, temveč z napovedovanjem učinkov, ki jih bodo v svetu povzročili naši praktično smotrni posegi.« Tehnoznanosti se ukvarjajo torej s problemi, ki niso plod znanstvenoteoretičnega preučevanja, ampak so jim jih od zunaj ideološko vsilile znanstvene politike (pri nas teme vsiljujejo na primer razpisi za znanstvene projekte). Tehnoznanstveno raziskovanje se mora izogibati teoretskemu razmišljanju, razmišljati pa mu tudi ni treba več o svojem lastnem početju. Znanost - izjeme seveda obstajajo - tako ne ustvarja več ničesar novega. Ustanove znanstvene politike so znanosti preprečile njeno znanstveno in družbeno kritičnost. Znanost je postala nemisleča, nepolitična in nečloveška. Znanstvenike pa so take znanstvene politike oropale poklicnega in človeškega dostojanstva in smisla. Pričujoči esej skuša vsesplošno neoliberalno uničevanje mišljenja misliti.

Ključne besede: neoliberalna (ekonomska) ideologija, uničevanje mišljenja, tehnoznanosti, korporativne akademske revije, »smrt« univerz, poblagovljenje izobraževanja, tehnokratiziranje jezika, matematizacija narave, ekonomije in družbe, gospodujoča moč zakonov, računajoče mišljenje, premišljajoče mišljenje, razsvetljenstvo, Bildung, javna uporaba uma, zasebna uporaba uma, skupne dobrine

Dr. Tomaž Sajovic, sajovic.tomaz@gmail.com 


\section{PROHIBITION OF THINKING - ABSTRACT}

Today's society is governed - borrowing the terminology from Slavoj Žižek and his text Leninova izbira (Lenin's Choice, 2010) - by the unwritten Denkverbot, or a "prohibition" of critical thinking. Its historical illustration is found in the notorious statement by Margaret Thatcher: "There is no alternative to neoliberalism." The neoliberal economic and social contra revolution started in the 1960s at the Department of Economics of the University of Chicago. Its most important proponent was American economist and winner of the Noble Prize in Economics Milton Friedman. His programme was extremely conservative: "Firstly, the governments must do away with all the provisions and regulations that prevent accumulation of profit. Secondly, they must sell all the assets that are owned by them and could be managed with profit by corporations. And thirdly, the funding of welfare programmes must be decreased dramatically." Milton Friedman "carefully" concealed this completely inhumane ideology, which "matched the interests of big multinationals completely", by formulating it through the academic "language of mathematics and science", and thus "transformed" it into impartial economic science. Neoliberal managing of the economy was thus supposedly freed from human subjectivity and became "solely" the fulfilment of scientifically determined natural laws. It therefore became impossible to either doubt it or think critically about it. It is assumed that what enabled neoliberal ideology to parasitize science is the fact that under neoliberalism science itself became "ideology". The Swiss-Canadian sociologist and philosopher Michel Freitag (19352009), in his book Le naufrage de l'Université (1995), named it technoscience: "Science is not concerned with studying the world anymore, but with predicting the effects caused in the world by our practically justified interventions." Technosciences focus on issues that are not results of scientifically-theoretical research but are externally and ideologically forced upon them by scientific politics (in Slovenia, for example, tenders for scientific projects dictate the topics). Technoscientific research must avoid theoretical thinking and is at the same time also absolved from self reflection. Science - with honourable exceptions - therefore ceased being creative. The institutions of scientific politics cut science from scientific and social criticism. Science became incognizant, apolitical and inhuman. At the same time, scientific politics deprived scientists of their professional and human dignity, as well as their purpose. This essay attempts to examine the universal neoliberal destruction of thinking.

Keywords: neoliberal (economic) ideology, destruction of thinking, technosciences, corporative academic journals, "death" of universities, commodification of education, technocratisation of language, mathematisation of nature, economy and society, governing power of laws, calculative thinking, reflective thinking, enlightenment, Bildung, public use of reason, common good

\section{KRATKA KRONOLOGIJA "UNIČEVANJA MIŠLJENIA«: OD MILTONA FRIEDMANA DO DRŽAVNE URADNICE NA MINISTRSTVU}

Od 50. do zgodnjih 70. let 20. stoletja se je v Čilu pa tudi drugod v Južni Ameriki vedno bolj krepila demokratična socialistična politika, ki si je prizadevala za blaginjo vseh ljudi. Taka razvojna politika pa je ogrožala tiste, ki blaginje niso želeli deliti z drugimi - mogočne ameriške multinacionalne korporacije. Zato jo je bilo treba uničiti z vsemi sredstvi. Tudi in predvsem z znanostjo in »pravilnim « izobraževanjem. Na čelo ekonomske in družbene kontrarevolucije se je povzpel temačni lik ameriškega ekonomista Miltona Friedmana (1912-2006), smrtnega sovražnika Rooseveltove napredne ekonomske in socialne politike, bolj znane kot New Deal. Friedmanov program je bil skrajno konservativen, danes bi rekli neoliberalen: »Prvič, vlade morajo odpraviti vsa 
določila in regulativo, ki preprečuje kopičenje dobička. Drugič, odprodati morajo vse premoženje, ki ga imajo v lasti in bi ga korporacije lahko vodile z dobičkom. In tretjič, financiranje socialnih programov morajo dramatično zmanjšati. « To popolnoma nečloveško ideologijo, ki se je »točno ujemala z interesi velikih multinacionalk «, je Friedman »skrbno« skril v akademizacijski »jezik matematike in znanosti«. Prav nič slučajno torej ni bilo, da so v oporišču svetovne ekonomske kontrarevolucije, na Oddelku za ekonomijo na Univerzi v Chicagu, Friedman, Arnold Harberger (1924-) in drugi profesorji »generacije študentov prepričevali, da ne smejo brati ničesar, kar bi jim povedalo kaj več o svetu, ampak morajo samo dobro obvladati orodja, s katerimi bodo lahko merili delna ekonomska (ne)ravnovesja v svetu «. V eni od univerzitetnih stavb je še vedno vklesan pomenljiv napis: Znanost je merjenje. Zadnja navedka sta iz prvega od dveh odprtih pisem Harbergerju in Friedmanu, ki ga je 6. avgusta leta 1974, na obletnico Hirošime, v protest proti njuni uničujoči ekonomski politiki v Čilu napisal nemško-ameriški ekonomski zgodovinar, sociolog in svetovno znani razvojni ekonomist Andre Gunder Frank (1929-2005), nekoč tudi sam Friedmanov študent, nikoli pa njegov »učenec«. Frank je Harbergerjevo in Friedmanovo ekonomsko politiko v Čilu popolnoma upravičeno imenoval »ekonomski genocid«(Gunder Frank, 1974).

Ekonomski neoliberalizem je že zelo kmalu doživel svojo »naturalizacijo«, in sicer kar v naravoslovju. Zanjo je poskrbel angleški biolog Richard Dawkins. Leta 2006 je nemški molekularni biolog, nevrobiolog, zdravnik in univerzitetni profesor Joachim Bauer (1951-) izdal knjigo Princip človeškosti, ki je leta 2008 izšla tudi v slovenskem prevodu. V njej je zapisal naslednje: »Leta 1975 je ameriški zoolog Edward O. Wilson objavil svojo knjigo Sociobiologija. Leto zatem je udaril na dan angleški biolog Richard Dawkins s knjigo Sebični gen [od leta 2006 jo lahko preberemo tudi v slovenskem prevodu; opomba je moja]. Wilson in Dawkins sta postulirala, da so akterji evolucije geni, ne pa živa bitja. Pogonska sila vsega življenja na tej Zemlji naj bi bil cilj genov, da se maksimalno množijo in se uveljavljajo proti konkurenci drugih genov. [...] Organizmi in osebki zdaj načeloma ne igrajo več odločilne vloge - razen te, da koristijo genom pri boju za njihovo preživetje. Antropološki model primarno sebičnega, kooperativnega samo zaradi lastne koristi, nazadnje pa samo za boj za preživetje programiranega človeka je bil s tem na dozdevno nesporen način še bolj zacementiran. Ali sta konkurenca in boj primarni gonilni sili, ki vodita obnašanje živih sistemov, je vprašljivo. Nanašajoč se na človeka so domneve napačne. Definitivno napačno je tudi, da so geni drug proti drugemu konkurirajoči akterji in da se - vsak gen tako rekoč proti ostalemu svetu - borijo za prevlado. Dejansko nihče ne ve, kaj so notranje nagonske sile in cilji evolucije. Vodilni znanstveniki s področja biologije in medicine, med njimi ameriška biologinja Lynn Margulis, menijo, da sta pojma 'konkurenca' in 'boj za preživetje' človeški konstrukciji, ki da prihajata iz gospodarstva in da sta od zunaj prenesena na biologijo. Biologija ne pozna nobenega uspešnostnega mišljenja, kakor to na primer prevladuje v gospodarstvu.« (Bauer, 2008).

Leta 2013 sta britanski teoretski fizik Peter Higgs (1929-) in celični biolog Randy Schekman (1948-) prejela Nobelovo nagrado, prvi za fiziko, drugi za fiziologijo ali medicino. Peter 
Higgs je v intervjuju, objavljenem 6. decembra leta 2013 v britanskem dnevniku Guardian, izjavil naslednje: »Težko si predstavljam, da bi v današnjem akademskem ozračju sploh našel dovolj časa in miru, da bi lahko storil tisto, kar sem storil leta 1964.« (Higgs, 2013.) Prav pretresljiv je njegov dvom, ali bi bila odkritja, kot je bilo njegovo odkritje Higgsovega bozona, danes, ko od akademikov zahtevajo obsesivno objavljanje člankov v najuglednejših revijah, sploh možna. Tri dni kasneje, 9. decembra, je prav tako v Guardianu objavil prispevek Randy Schekman. Že iz naslova prispevka - Kako revije kot Nature, Cell in Science škodujejo znanosti - je razvidno, da je Schekman napadel samo »svetišče sodobnega ideološkega akademiziranja znanosti: najuglednejše znanstvene revije, ki po svetu veljajo kot nesporni »prostor « znanstvene »odličnosti« (Schekman, 2013). Schekmanovi argumenti za takó kritično stališče so naslednji. Objave v najuglednejših revijah na razpisih same po sebi zagotavljajo financiranje znanstvenih projektov in zaposlitve na univerzah. Vendar te revije ne objavljajo vedno samo izvrstnih člankov. Poleg tega te revije agresivno oglašujejo svoje tržne znamke, pri čemer jih bolj zanima prodaja kot pa spodbujanje najbolj pomembnih raziskav. Pri tem si pomagajo s spornimi faktorji vpliva, ki so za znanost tako škodljivi kot nagrade v bančništvu. Taka tržna logika spodbuja objavljanje člankov z vznemirljivimi in izzivajočimi trditvami, v skrajnem primeru pa tudi prispevkov, ki so jih revije zaradi napačnih dognanj kasneje prisiljene umakniti - ali pa tudi ne. Vse to pa neizogibno škoduje znanosti, ki jo ustvarjajo znanstveniki. Schekman (2013) iz tega izpelje naslednje sklepe. Za znanstvenike so rešitev revije na spletu s prostim dostopom, ki objavljajo kakovostne članke brez umetnih omejitev, ki jih lahko bere vsakdo in ki ne poznajo dragih naročnin. Mnoge izdajajo znanstveniki sami, ki ocenjujejo kakovost člankov, ne da bi se ozirali na citiranost. Odločanje o financiranju znanstvenih raziskav in zaposlitvah na univerzah naj ne temelji več na tem, v katerih revijah znanstveniki objavljajo. Pomembna je namreč kakovost znanosti, ne pa blagovna znamka revije. Najpomembnejše pa je, da se znanstveniki sami uprejo. Schekman in njegov laboratorij tako ne bosta več objavljala v revijah Nature, Cell in Science, ker škodujejo znanstvenemu procesu, pozivata pa tudi druge znanstvenike, da storijo enako. »Znanost mora zrušiti tiranijo 'najuglednejših' revij. Rezultat bo boljše raziskovanje, ki bo bolje služilo znanosti in družbi.« Schekman - ki je, ponovimo, naravoslovec - je v svojem prispevku predstavil pravo družbenokritično analizo pogubnih učinkov kapitalistične neoliberalne »akademizacije « in s tem družbene pasivizacije znanosti in univerz v sodobnem svetu. »Akademizacija « na vsakem koraku kaže svojo zločesto družbeno naravo: izobraževalne in raziskovalne dejavnosti na univerzah in inštitutih podreja togemu sistemu pravil, predpisov in načel. To pa pomeni, da je tudi »proizvod « teh dejavnosti - védnost sama - »ujeta « v ta togi sistem pravil, predpisov in načel. Natančneje in brezobzirneje povedano, ta togi akademizacijski normativni sistem zdaj »odloča « o tem, kaj sploh je védnost, še več, »odloča « lahko celo o tem, ali bo védnost sploh »proizvedena«. Ta védnost pa je po Schekmanu očitno neoliberalna (Schekman, 2013).

Leta 2014 je nova slovenska ministrica za izobraževanje že na začetku svojega mandata napovedala uvajanje podjetniških vsebin v splošne šole. Kar v nekaterih šolah sicer že počnejo (Ali podjetništvo sodi v splošne šole, Dnevnik, 3. novembra 2014) (Mlakar, 2014). Stališče vodje sektorja za srednje šole na ministrstvu za izobraževanje, torej še ene visoke 
državne uradnice na ministrstvu, je popolnoma enako. Nedavno je namreč izjavila, da mladi »po končanem izobraževanju pričakujejo službo, ki pa je ni «, in dodala, da je danes službo treba ustvariti, to pa je v nasprotju $\mathrm{s} »$ tipičnim slovenskim razmišljanjem《. Njen nasvet za spremembo poslanstva vrtcev in šol je za razmišljujočega in čutečega človeka pretresljiv: »Posameznik mora svoje znanje znati prodati. Potem je izobraževalni sistem opravil svojo nalogo. « Klemen Košak (2014) ima v svojem članku Krivdo nosim sam. O spornosti koncepta "podjetnosti « vizobraževanju popolnoma prav, ko trdi, da so trditve vodje sektorja za srednje šole na ministrstvu za izobraževanje dobronamerne le, če zaostrovanja razmer na trgu delovne sile (nezaposlenost, prožnost in negotovost delovnih razmerij) ne razumemo kot posledico subjektivnih, torej političnih odločitev, ampak kot objektivno dejstvo, na katero ljudje nimajo vpliva - prav neoliberalna ekonomska politika pa je tista, ki sebe prikazuje kot nekaj objektivnega, nekaj naravnega in neizogibnega torej. Ko zaostrovanje razmer na trgu delovne sile v skladu s to ideologijo »razumemo « kot objektivno dejstvo, se spremeni tudi naloga vzgoje in izobraževanja. Profesor Marjan Šimenc s Pedagoške fakultete v Ljubljani to spremembo opiše z naslednjimi besedami: »Šola počasi ni več mesto kritičnega mišljenja, temveč mesto oblikovanja osebnosti, ki bo ustrezala trenutni obliki globaliziranega neoliberalnega kapitalizma.« (Košak, 2014). Človek tako že na začetku svoje življenjske poti izgublja svojo človeško svobodo. Misleči človek - Homo sapiens pred našimi očmi izginja in postaja vedno hitreje le nemočni in depresivni poblagovljeni človek - človek, ki ustvarja le blago in je tudi sam le blago, mišljenja pa mu mračna in patološka friedmanovska neoliberalna ideologija ne »dovoljuje« več.

Modernega človeka lahko globoke depresivnosti ozdravi - kot je v knjigi Duša na delu (v slovenskem prevodu je izšla leta 2013) zapisal italijanski marksistični in medijski teoretik ter kulturni aktivist Franco Berardi-Bifo - le »velikanska osvoboditev življenja od družbe kot tovarne «(Berardi-Bifo, 2013). Pričujoči eseji so moja osebna »terapija«, ki jo moramo razumeti kot obliko političnega boja. Morda bo njihovo branje olajšalo dušo še komu.

\title{
ZAVRGEL SEM OBRABLJENA IMENA IN RAZDRL VARLJIVI RED LEPOTIJE
}

Leta 1963 je Edvard Kocbek izdal pesniško zbirko Groza. V njej lahko preberemo tudi pesem Prošnja:

\author{
Zmeda je bila vedno bolj zavratna, \\ moje besede pa brez čarovne moči. \\ Zavrgel sem obrabljena imena \\ in razdrl varljivi red lepotije, \\ besedam sem odvzel zapeljivi zven \\ in glasove izpostavil začetku, \\ da jih naravne sile izmučijo \\ in besi in milost preskusijo. \\ Zdaj sem srečen kakor lovec, \\ ko sredi strmeče zasede odkrije,
}


da se zveri odvrnejo od krutosti, kadar jih kličemo s klici ljubezni, že jih snubim tiho in zapeljivo, vračam jih v začetna stanja, šepetam, jecljam, zavijam in tulim, venomer izgovarjam starodavni obrazec:

Velika sla, skrita v stvareh, prebudi se, razburi se in se razdivjaj, napolni mi imena z neizrekljivostjo in jim daj sveto norost minljivega, da bodo postala neusmiljena in čista kakor kiti in sloni in termiti, ki prenesejo ciklone, potrese in starost in se najtišje pobratijo s smrtjo.

In čuj, glasovi se že prebujajo $v$ podobah prvinske izmerjenosti, že vzdigujejo svoje ponosne glave in se pripravljajo na novo slavje, že vzhaja vroči zamorski večer, že slišim bobne in snujoči ritem, že začenjajo jecljati in tuliti, že oznanjajo več od samih sebe.

Pesem govori o človekovi dramatični usojenosti na bivanje v svetu, ki človeku kljub sizifovskim poskusom, da bi ga razumel in se v njem udomačil, ostaja večna uganka. Edino kolikor toliko trdno in očitno znamenje teh človekovih sizifovskih poskusov je jezik. Ko človek v obupu ne najde več pristnega stika s svetom ali pa mu ga družba s svojo nepravično ureditvijo zahrbtno odteguje, postanejo tudi njegove besede nesmiselne, »obrabljene« in »brez čarovne moči«. Ko pa človek začne vzpostavljati ekstatično bitno razmerje s svetom, se mu tudi jezik začne »prenavljati« in polniti s »čarovno močjo«. Ali s Kocbekovimi besedami še nekoliko drugače: ko se človek odpre »celostnemu, darežljivemu in odrešujočemu doživljanju vsega, kar je« - z drugimi besedami, resnici vsega živega in neživega na tem svetu -, mora zavreči tudi »obrabljena imena«, razdreti »varljivi red lepotije «, besedam odvzeti »zapeljivi zven« in glasove izpostaviti »začetku«, »da jih naravne sile izmučijo in besi in milost preskusijo«. Avstrijska pisateljica Elfriede Jelinek (1946-) je s sebi lastno ostrino zapisala nekaj podobnega: »Da bi jezik lahko izražal resnico, ga moramo mučiti« - ali drugače povedano, resnico lahko pripovedujemo le v jeziku, ki ga z osebno pričevanjsko močjo ves čas stvariteljsko »prenavljamo« (Nobelprize, 2004). Elfriedi Jelinek so za njeno pisateljsko ustvarjanje leta 2004 podelili Nobelovo nagrado za literaturo prav z utemeljitvijo, da »z nenavadno jezikovno energijo razkriva absurdnost družbenih stereotipnih vzorcev obnašanja 
- torej tudi jezikovnih (pripomba je moja) - in njihovo gospodujočo moč«. Utemeljitev je za naše razpravljanje izredno pomembna, saj ustvarjalnega, nestereotipnega in »neobrabljenega« izražanja kot človeške vrednote ne »omejuje« le na človekovo pesniško ustvarjanje, ampak ga razume kot bistveno prvino človekovega stvariteljskega in darežljivega družbenega sobivanja s soljudmi in svetom nasploh. Kocbek je družbeno etičnost ustvarjalnega, nestereotipnega izražanja pesniško ubesedil v verzu »Zdaj sem srečen kakor lovec, / ko sredi strmeče zasede odkrije, / da se zveri odvrnejo od krutosti, / kadar jih kličemo s klici ljubezni ... « (poudarek je moj), še jasneje pa jo je izrazil v eseju Misli o jeziku (Kocbek, 1985):

»[N]ezadostnosti in slabosti jezika ne gredo na rovaš njegove [zgradbe], temveč so posledica bitne nemoči njegovega izraževalca. Čim jasnejši je človekov vzgib, tem resničnejši je njegov izraz. Čim bolj je človek zgodovinsko razgiban, tem izvirneje se izraža, in čim bolj družbeno je prepričan, tem odgovorneje in pogumneje se izraža. Družba se torej ne sme bati niti subjektivizacij niti spontanosti. [Uveljavitev] človeka v njegovih pravicah in dolžnostih do polnega izraza, do vprašanja, dvoma, do sodbe, zavračanja in pritrjevanja, do soglašanja in prepričanja je varna pot do napredka in svobode, do demokracije in do stvariteljskega izraza.«

Vendar se je Kocbek boleče zavedal, da ima njegovo zanosno pozivanje k stvariteljskemu jeziku in $\mathrm{z}$ njim $\mathrm{k}$ ustvarjanju etičnega sobivanja $\mathrm{z}$ ljudmi in svetom v sodobni družbi bolj vlogo zarotitvenega obrazca, ki težko ali pa sploh ne najde svojega naslovnika, kajti »[b]esede in stavki se ne polnijo več z vsebino osebnega življenja in prepričanja. Pojema osebno snovanje, iniciativno delo, celostno izražanje, odkrito pričevanje, pošteno ugovarjanje. Zapušča nas kohezijska ekstaza, ostajamo brez zavezujoče vizije o kulturi, brez jasnega moralnega zakonika, celo brez družbene osrednje vrednote.« (Prav tam, 1985.) Tako utemeljitev Nobelove nagrade Elfriedi Jelinek kot Kocbekovo razmišljanje o jeziku prepričljivo kažeta, da v sodobni družbi vedno bolj izginjata prostor in možnost za osebno, izvirno besedo, z vedno bolj nasilno gospodovalnostjo pa se uveljavlja popolnoma neosebna in poenotujoča, zgolj uporabnostna, birokratska in tehnokratska govorica politike, znanosti in ekonomije, ki vztrajno briše še zadnje sledove človeškosti.

Najbolj absurdna posledica in najbolj pretresljiva podoba sodobnega etično »izvotljenega« človeka je bil Adolf Eichmann, nacistični esesovski podpolkovnik, ki je med drugo svetovno vojno organiziral prevoze Judov v koncentracijska taborišča. Po koncu vojne je pobegnil v Argentino, kjer so ga leta 1960 sodelavci izraelske tajne službe Mossad ugrabili in prepeljali v Izrael. Na sodnem procesu v Jeruzalemu so ga obsodili na smrt in leta 1962 obesili. Obsodba je bila deležna številnih nasprotujočih se odzivov. Eden najbolj tehtnih je leto kasneje izšel tudi v knjižni obliki z naslovom Eichmann v Jeruzalemu: banalnost zla. Knjigo, ki jo od leta 2007 lahko preberemo tudi v slovenskem prevodu, je napisala znamenita nemško-judovska filozofinja Hannah Arendt (Arendt, 2007).

Kaj se je pravzaprav zgodilo v Jeruzalemu? Na sodnem procesu so obsodili človeka zaradi popolnoma nove vrste zločinov, ki jih ni bilo mogoče najti v nobenem zakoniku. Ti zločini 
so bili administrativni, torej "pravni« zločini, ki jih je organiziral državni aparat nemške nacistične države, in so bili »nedvomno opravljeni znotraj 'pravnega' reda«. Ta totalitarni »pravni« red je bil tako »dovršen «, da je pred njim klonila celotna družba v tretjem rajhu. Eichmann je bil njegov najbolj absurdni »proizvod «. Ni bil nikakršen krvavi morilec iz Shakespearjevih tragedij, kot sta bila Macbeth in Rihard III., nikomur ni skrivil lasu na glavi, bil je le vzoren, suhoparen birokrat, ki je marljivo izvrševal ukaze in zakone. Na sojenju je celo izjavil: »Uradniški jezik je edini, ki ga znam.« Najbolj pretresljivo je bilo, da svojega »pokornega državljanstva« sploh ni mislil, da »preprosto ni nikoli spoznal, kaj dela«, da nikoli ni razumel, da bi sploh imel kaj s pobijanjem Judov: »Nikoli nisem ubil nobenega Juda ali pa Nejuda [...]. Nikoli nisem dal ukaza, naj ubijejo bodisi Juda ali Nejuda [...].« Hannah Arendt je to nesposobnost mišljenja imenovala banalnost zla, Eichmannov pravni zastopnik dr. Servatius pa je v svojem sklepnem govoru izrekel misel, ki je bila resničnejša, kot si je sploh lahko predstavljal: »Obtoženec je izvršil 'državne akte', to, kar se mu je zgodilo, se v prihodnosti lahko zgodi vsakomur, s tem problemom se spopada ves civilizirani svet.« Problem, ki se je na Eichmannovem sojenju v Jeruzalemu razkril v vsej svoji ostrini, je bil srhljiv: človekov etični občutek za pravičnost se je znašel dobesedno »zunaj« zakona, pod pritiskom zakona pa je začel tudi sam polagoma razpadati - v tretjem rajhu je skoraj popolnoma izginil in zdelo se je, da je bil to le »skrajni ekscesni primer«. Vendar branje knjige Evgenija Pašukanisa Splošna teorija prava in marksizem (1924) dokazuje, da moramo izvir pojava iskati kar v samem jedru sodobnega, kapitalističnega prava. V njem - po nekaterih raziskovalcih filozofije prava - »dolžnost, ki jo zapoveduje zakon, nima ničesar skupnega z 'notranjo', osebno moralno dolžnostjo, zato tudi podreditve zakonom ne moremo ločevati od podreditve moči sami«. Etični občutek za pravičnost, zakoreninjen globoko v vsakem človeku - imenujemo ga tudi vest -, je tako postal le neobvezen »nadomestek « za gospodujočo moč zakona in njegove besede, jezika torej (morda je prav zaradi tega razloga Eichmann znal samo uradniški jezik). S tega stališča je zdaj bolj razumljivo Eichmannovo »preoblikovanje« vesti v pokornost ukazom in zakonom, prav to pa nam pojasnjuje tudi njegovo globoko in iskreno razočaranje nad razsodbo sodišča: »Njegova krivda je izhajala iz pokornosti [ukazom in zakonom], pokornost pa je na glasu kot krepost. Njegovo krepost so zlorabili nacistični voditelji. [...] Bil je žrtev, in le voditelji so si zaslužili kazen.« Eichmann se osebno - kot človek - ni čutil krivega.

Toda tudi sodišče v Jeruzalemu se je izognilo svoji edini nalogi, ki jo je kot kazensko sodišče imelo, in ni obravnavalo Eichmannove osebne, človeške odgovornosti in krivde pri pobojih Judov. Hannah Arendt se je morala strinjati z Eichmannom in njegovim odvetnikom, da so Eichmanna obsodili predvsem kot »grešnega kozla« za vse hudo, ki se je zgodilo judovskemu ljudstvu. Na sojenju v Jeruzalemu »ni šlo več za [...] določenega posameznika na zatožni klopi«, temveč prej za Nemce nasploh ter za antisemitizem in totalitarno zločinsko vladavino $\mathrm{v}$ tretjem rajhu $\mathrm{z}$ vsemi strahotnimi posledicami vred. Tako pri Eichmannovih ravnanjih kot pri razsodbi sodišča $v$ Jeruzalemu je največji poraz torej doživelo prav to najpomembnejše: osebna odgovornost. Za Hanno Arendt je bil Eichmann kljub svojemu zagotavljanju, da je bil le pokoren zakonom, nedvomno osebno kriv, ker je izvajal, s tem pa dejavno podpiral politiko množičnega pobijanja: »Kajti 
politika ni otroški vrtec; v politiki sta pokorščina in podpora eno in isto.« Eichmannova nesposobnost mišljenja je bila, da je »mislil«, da pokorščina zakonom ni pomenila tudi podpore politiki množičnih zločinov. Prepričan je bil, da je pokorščina zakonom najpomembnejša vrlina v življenju, ni pa bil sposoben videti, da je prav zaradi te »vrline « postal idealen izvajalec strahotnega uničevanja življenj - zanj je resničnost pač bila le tisto, kar je bilo zapisano v zakonih.

Hannah Arendt je Eichmannov nenavadni lik lahko razumela, ker je razumela, da tudi moderna država s preoblikovanjem vsega živega in neživega $\mathrm{v}$ administrativni mehanizem zakonov množi podobne poslušne, nesvobodne, razčlovečene like. Ker tudi tem likom postaja edina resničnost vedno bolj le tisto, kar je zapisano v zakonih, se tudi ti liki lahko sporazumevajo samo še v »uradniškem«, stereotipnem, obrabljenem jeziku. V bolj izvirnem in ustvarjalnem »kocbekovskem« jeziku se bodo lahko sporazumevali šele takrat, ko bodo zopet odkrili pristno in osebno odgovorno razmerje z vsem živim in neživim na tem svetu - z drugimi besedami, ko si bodo priborili dejansko svobodo mišljenja, ki pomeni, kot je zapisal Slavoj Žižek v Leninovi izbiri (2010), predvsem svobodo kritičnega preizpraševanja gospostva državnega administrativnega mehanizma zakonov in nepravičnosti kapitalističnega ekonomskega sistema. ${ }^{1}$

\section{LJUDJE "NIMAMO« SKUPNIH DOBRIN, AMPAK "SMO" SKUPNA DOBRINA MI SAMI}

Edvard Kocbek je v eseju Misli o jeziku zapisal (Kocbek, 1985), da »le materinski jezik ustvari bitni stik med človekom in resničnostjo, le v njem se začne proces človekove preobrazbe in v nekem smislu tudi preobrazbe sveta«. V človekovo jezikovno izražanje je zato vedno vtisnjeno njegovo razmerje do sveta. Toda že Kocbek se je boleče zavedal, da v sodobni tehnokratski družbi osebno, izvirno besedo brezobzirno izpodriva neosebna, birokratska in tehnicistična govorica politike, znanosti in ekonomije. Kocbekova analiza sodobne družbe je temačna - vendar osupljivo pravilna: »Sredstva za obvladovanje narave postajajo tudi sredstva za obvladovanje človeka, celo za normiranje njegove notranjosti. Tehniško pojmovanje spreminja človeka v zgolj postavko, v kolesce družbene aparature. Tehnicizmu je vse le predmet iznajdbe in porabe, proizvodnje in potrošnje, informacije in predpisa.«

Modernemu človeku postaja edina resničnost vedno bolj le tisto, kar je zapisano v zakonih, zato se tudi sporazumeva lahko samo še v »uradniškem «, neosebnem in obrabljenem jeziku. V bolj izvirnem in ustvarjalnem »kocbekovskem« jeziku se bo lahko sporazumeval šele takrat, ko bo zopet odkril odgovorno razmerje z vsem živim in neživim na tem svetu - z drugimi besedami, ko si bo priboril dejansko svobodo kritičnega mišljenja.

Vprašanje je, kako razviti to sposobnost kritičnega mišljenja. Na načelni ravni je odgovor razmeroma lahak - človek si je v ta namen omislil ustanove védenja: šole, univerze,

1 Besedilo je kot uvodnik izšlo v mesečniku za poljudno naravoslovje Proteus (2013, letnik 76, številka 3). 
znanstvene inštitute. Vendar je s tem védenje oziroma mišljenje tudi institucionaliziral. »Ujel« ga je v mrežo zakonov in predpisov, z njo pa »določil«, kakšno védenje je družbeno »zaželeno«. To je lahko storil le tisti, ki je imel moč, z razvojem kapitalizma predvsem sodobna nacionalna država. Ustanove védenja so tako postale njen najtrdnejši ideološki aparat. Zadnjo tako institucionalizacijo védenja pri nas pomeni osnutek novega Zakona o visokem šolstvu, ki je predvsem zaradi možnosti uvajanja plačljivega študija že do zdaj dvignil veliko prahu. Tu nas zanima le zakonodajalčevo razumevanje védenja. V enem od členov v splošnih določbah osnutka zakona najdemo zapisano navidez popolnoma nevprašljivo formulacijo, ki so jo ljudje že zdavnaj in brez večjega premisleka vzeli za svojo: »Univerza [...] neposredno ali prek svojih članic v izobraževalnem procesu posreduje spoznanja z več znanstvenih oziroma umetniških področij ali disciplin. (Osnutek Zakona o visokem šolstvu, 2014.) V resnici je formulacija nekaj najbolj vprašljivega. V njenem skrajno abstraktnem tehnokratskem jeziku so učitelji in študenti postali »nevidni«, »vzniknile« pa so ustanove - univerza in članice. Človek je »poniknil« v ustanovi oziroma sistemu. Še bolj sporna je uporaba besedne zveze posredovati spoznanja. Glagol posredovati predpostavlja ločitev na tiste »nevidne« v formulaciji - torej učitelje -, ki imajo védenje (spoznanja) in ki ga kot nekakšen »predmet«, »izgotovljeni izdelek«, »nekakšno blago« predajajo tistim tudi »nevidnim« v formulaciji - torej študentom -, ki ga nimajo, v »uporabo«. Univerza se tako banalizira v skupnost »prodajalcev « in »kupcev«, v trgovskem besednjaku »potrošnikov«. Tako razumevanje vloge univerze je že leta 1914 v svojem eseju Življenje študentov kritiziral Walter Benjamin, ki je zapisal, da »na študij« ne smemo gledati »kot na sredstvo za zunaj obstoječe smotre in na študentski čas le kot na prehod do poklica in službe«. Že takrat je videl, da univerze »zahtevajo le nekaj fragmentarnega, saj je cilj njihovega etosa $v$ najboljšem primeru razširjanje ali popularizacija znanja (Benjamin, 1914). Besedna zveza posredovati védenje kot trdo jedro razumevanja vloge univerze je torej »zakrinkani « miselni predhodnik vedno bolj razširjenega prepričanja, da je védenje res blago, ki ga je mogoče prodajati kot katero koli drugo blago. Vendar to prepričanje spregleduje, da védenje v dejanskosti ne obstaja, če ga ljudje ne razumejo ter ga ne plemenitijo s svojim življenjem in svojega življenja v svetu z njim. V tem smislu védenje vedno na novo ustvarjamo, na univerzi v sodelovanju med učitelji in študenti, ti pa v sodelovanju z ljudmi zunaj univerze. Le tako lahko spoznavanje sveta in življenja $\mathrm{v}$ njem - to bistvo in usoda vrste, ki sebe imenuje Homo sapiens oziroma misleči človek zares postane skupna dobrina. Pravi absurd je, da je prav ta misleči človek to svoje bistvo začel že zdavnaj banalizirati, potem pa še lastniniti in prodajati in s tem omejevati dostop prav do njega. Torej - paradoksno - do samega sebe. Poskus uzakonitve plačljivega študija v novem Zakonu o visokem šolstvu pomeni prav to, predlagateljem pa je pravno utemeljitev »spisalo« kar ustavno sodišče v svoji odločbi (14. aprila leta 2011). Nas zanimata predvsem dva stavka v njej. Prvi se glasi: »Javna služba je [...] normativni pojem in ne dejanski.«Stavek je pravno verjetno pravilen, pripoveduje pa nekaj skrajno problematičnega: javna služba je samo tisto, kar država zapiše v zakon, taka »poljubna«, »samovoljna« opredelitev javne službe pa pravzaprav razveljavlja sámo vrednost izobraževanja kot javne (skupne) dobrine, ki naj bi jo javna služba zagotavljala. Kar prostodušno pravi 
drugi stavek: »Izobraževalna dejavnost na primer tako sama po sebi ni javna služba, saj lahko poteka vsebinsko enako po tržnih merilih ali v okviru pravnega režima javne službe.«(ZVIS, 2013, 2014.) Prav osupljivo je, da ustavno sodišče izobraževalne dejavnosti sploh ni sposobno »misliti« zunaj zgolj formalnih pravnih okvirov. Prepričano namreč je, da je le od ustreznega pravnega okvira odvisno, ali bo izobraževanje javna (skupna) dobrina ali pa tržno, prodajno blago, pri tem pa naj bi pravni okvir sploh ne vplival, vsaj ne pomembno, na vsebino izobraževalne dejavnosti (kar seveda ne drži). Ustavno sodišče je za vsebinsko razliko med izobraževanjem kot javno (skupno) dobrino in izobraževanjem kot tržnim, prodajnim blagom »slepo«. Prav ta abstraktna vsebinska »brezbrižnost « pa je temeljna značilnost prava v kapitalizmu. Ruski pravni teoretik Evgenij Pašukanis je v svoji knjigi Splošna teorija prava in marksizem (2014) vzrok za abstraktni značaj prava poiskal v gospodujočem bistvu kapitalistične proizvodnje - blagu. Pri odgovoru, kaj sploh je blago, se bom skliceval na knjigo Spreminjajmo svet brez boja za oblast (2002), ki jo je napisal John Holloway. Blago je predmet, ki smo ga proizvedli, vendar stoji zunaj nas. Ko je blago proizvedeno, zaživi lastno življenje, naprodaj na trgu - človeško delo, ki ga je proizvedlo, pa je pozabljeno. »Vstajenje« blaga v kapitalizmu hkrati pomeni torej »izbris« človeka. Zdaj namreč tudi človek postaja blago, z njim pa, kot smo videli, tudi védenje sámo. Pričevanje študenta Pravne fakultete na Univerzi v Beogradu Miljana Jelića v zaključku recenzije Pašukanisove knjige, ki jo je objavil na internetu, je pretresljivo: »Pozitivizem ostaja - za nas, študentke in študente -, če v nič drugem, potem v odnosu med učencem in gradivom. Študiranje je omejeno na učenje pravnih norm, ki so taksativno naštete $\mathrm{v}$ učbeniku, na pamet, naloga študenta pa je popolnoma spominska da si zapomni, kolikor si pač lahko, pri čemer se ne opira na logično sklepanje, ampak na razpored delov besedila ali barvo flomastra, s katerim je označil kakšno besedo. Praktična uporaba naučenega je enaka ničli, prav zveza teorije in prakse pa je dialektična vez, ki iz podatkov, ki jih imamo, šele ustvarja resnično znanje.« (Jelić, 2014.)

Jelić ima prav: védenje, ki je razumljeno in »proizvajano« kot blago, ni resnično znanje, to lahko postane le, ko se povežeta teorija in praksa - takrat torej, ko postane skupna (javna) dobrina. Tako si ga je predstavljal že tudi Walter Benjamin leta 1914 v svojem eseju Življenje študentov (Benjamin, 1914). Enakega mnenja je prav gotovo tudi italijanski pravni teoretik Ugo Mattei, za naše razpravljanje pa je branje njegove razprave Država, trg in nekaj predhodnih vprašanj o skupnih dobrinah, objavljene tudi na internetu leta 2011, posebej pomembno še iz enega razloga: Mattei v njej namreč predstavlja svoj teoretični pogled na pomen skupnih dobrin v življenju nasploh (Mattei, 2011).

Skupne dobrine (voda, kultura, internet, zemlja, izobrazba oziroma védenje) po njegovem prepričanju predvsem nikakor niso »blago«, ampak nekaj popolnoma drugega - so namreč skupno razumevanje resničnosti. Kar pomeni, da ljudje »nimamo« skupnih dobrin, ampak smo skupna dobrina mi sami - kot neizogibni del okolja. Še več, skupna dobrina je življenjsko sožitje med ljudmi in okoljem samo - od tega je namreč odvisno preživetje tako nas in naših skupnosti kot tudi okolja. Mattei je zato prepričan, da je pri urejanju razmerij v družbi kapitalistični pravni sistem, ki temelji na gospostvu blaga, treba zamenjati 
s pravnim sistemom, ki bo temeljil na skupnih dobrinah. Pri oblikovanju takega pravnega sistema bi se morali zgledovati po »ekosistemu «. V njem bi človeška skupnost bila povezana s horizontalnimi vezmi v omrežje, kjer bi bila moč razpršena. Ker bi bile koristi skupnosti temeljni družbeni cilj, bi sodelovanje - in ne tekmovanje - med ljudmi postalo nekaj samo po sebi razumljivega. Človeku in naravi bi tako bilo povrnjeno dostojanstvo, ki mu ga je vzelo gospostvo blaga v kapitalizmu.

Boj za uveljavitev skupnih dobrin v družbi ne bo lahak. Kot kaže spremno besedilo Primoža Krašovca (2013) Teorija in praksa levice po levici v knjigi Vse po starem: gospodarska kriza in polom kapitalizma, ki jo je napisal Paul Mattick (2013), na univerzo kot zbirokratizirano ustanovo pri tem ni mogoče računati (pre)več. Akademsko družboslovje družbene boje, tudi tistega za uveljavitev skupnih dobrin, vidi zgolj kot predmet raziskovanja. Tako pridobljena védnost je namenjena le habilitacijskim komisijam, javni upravi ali pa vodstvom zasebnih podjetij, ne pa množicam. Za akademsko družboslovje so množice (ali »družbene skupine«) le še predmet upravljanja s strani države ali kapitala. Zato ga popularizacija védenja v kakšnem bolj izvirnem in splošno razumljivem jeziku tudi ne zanima več.

Je sodobni človek danes še sposoben »deakademizirati« svojo raziskovalno radovednost ter jo odgovorno, pogumno in zanosno sprostiti $\mathrm{v}$ »areni življenja «? Od odgovora nanj bo odvisna naša usoda in usoda sveta. ${ }^{2}$

\section{RAČUNAJOČE MIŠLJENJE}

Francoski sociolog, antropolog, filozof in znameniti javni intelektualec Pierre Bourdieu (1930-2002), eden od najostrejših in najbolj neizprosnih kritikov neoliberalizma, je leta 1998 izdal knjigo Dejanja upora: Proti tiraniji trga in v njej zapisal tudi naslednjo misel: »Galileo je rekel, da je naravni svet napisan v matematičnem jeziku. Neoliberalni ideologi nas želijo prepričati, da ekonomski in družbeni svet sestavljajo enačbe. Oborožen z matematiko (in močjo nad mediji) je neoliberalizem postal najvišja oblika sociodiceje (izraz pomeni teoretično opravičevanje posebnih pravic in ugodnosti vladajočih skupin in ravnanja z vladanimi; opomba je moja), ki se je začela pojavljati pred kakšnimi tridesetimi leti kot 'konec ideologije' ali, nedavno, kot 'konec zgodovine'.«(Bourdieu, 1998.)

Misel je na prvi pogled nenavadna, saj Bourdieu v njej »izenačuje« Galileja in neoliberalne ideologe - za prvega je v matematiki »utemeljen « naravni svet, za druge (tudi) ekonomski in družbeni svet.

Za običajno pamet pa je misel tudi sporna, saj se ne moremo znebiti občutka, da Bourdieu v njej na neki način - ki ga moramo še premisliti - tudi vrednostno »izenačuje« Galilejev pogled na svet, ki je pomenil rojstvo moderne znanosti, s prepričanjem neoliberalne ekonomske in družbene ideologije, da je v gospodarstvu treba brezpogojno uvesti svobodni

2 Malce spremenjeno besedilo je kot uvodnik izšlo v mesečniku za poljudno naravoslovje Proteus (2013, letnik 76, številka 4). 
trg, odpraviti določila, ki preprečujejo kopičenje dobička, umakniti državo iz gospodarstva, sprivatizirati državno premoženje ter čim bolj skrčiti javni sektor in socialne pravice. Angleška ministrska predsednica Margaret Thatcher je to brezpogojnost izrazila v znamenitem stavku: »Neoliberalizem nima alternative, « ob njem pa je - kot je v svojem intervjuju v Delu 27. maja leta 2013 izjavila ameriška in francoska politična teoretičarka in aktivistka Susan George - »delavce na Zahodu spreletaval srh in je družinam ledenela kri [...], njena retorika je pomenila, da prihajajo strašne reči: izgubljanje služb, krčenje sociale, klestenje države« (George, 2013).

Dokazov, da so učinki neoliberalizma v resnici uničujoči, ni treba naštevati, danes jih čutimo vsi. Večji problem je, zakaj Bourdieu nima preveč pohvalnega mnenja niti o Galileju in novoveški znanosti. Vzrok za to je očitno treba iskati v neki na prvi pogled »nevidni« temeljni protislovnosti »galilejevske« novoveške znanstvene matematizacije naravnega sveta. Da bi lahko razumeli Bourdieujevo stališče, moramo brati znamenito Dialektiko razsvetljenstva, ki sta jo napisala judovski filozof in sociolog Max Horkheimer (1895-1973) ter nemški filozof in sociolog Theodor Wiesengrund Adorno (1903-1969). Izšla je leta 1944, v slovenščino pa je bila prevedena leta 2002. Za naše razmišljanje je posebej pomembno tisto besedilo v njej, ki ima naslov Pojem razsvetljenstva. »Program razsvetljenstva je bilo« - kot začneta svoje razmišljanje Horkheimer in Adorno - »odčaranje sveta. Hotelo je razkrojiti mite in strmoglaviti domišljijo z védenjem.« (Horkheimer in Adorno, 2002.) Ali kot je v slovitem eseju V slavo védenju (1592) sijajno in nenavadno odkritosrčno zapisal eden od očetov razsvetljenstva, angleški filozof, znanstvenik, pravnik in državnik Francis Bacon (1561-1626): »Premoč človeka tiči [...] v védenju, o tem ni nobenega dvoma. V njem je spravljeno marsikaj, česar kralji z vsemi svojimi zakladi ne morejo kupiti, nad čimer ne morejo izkazovati moči, o čemer jim njihovi ogledniki in ovaduhi ne morejo poročati ničesar; morjeplovci in raziskovalci pa ne morejo odpluti v nedotaknjene dežele, iz katerih to marsikaj prihaja. Dandanes obvladamo naravo zgolj $v$ svojih mislih in smo podvrženi njeni prisili; moramo ji pustiti, da nas vodi pri iznajdevanju, zato da bi ji zapovedovali v praksi.«(Bacon, 1592.)

Poudarjeni deli Baconovega besedila kažejo ključno spremembo v človekovem dojemanju sveta, ki se je začela uveljavljati na začetku novega veka. Stari Grki so se še čudili stvarem in bitjem na svetu zaradi njih samih - čudili so se jim preprosto zato, ker obstajajo. Z eno samo besedo poíesis (pomenljivo je, da današnja beseda poezija, pesništvo, izvira prav iz nje) so poimenovali tudi vsakršno proizvajanje tistega, česar še ni, v darežljivo skrivnostnost obstajanja - tako v rokodelstvu in umetnosti kot v naravi sami (Martin Heidegger: Vprašanje po tehniki, 1953, v slovenskem prevodu 2003). Za stare Grke celo rokodelstvo ni bilo nič zgolj tehničnega v novoveškem pomenu besede, ampak »pesništvo«. Tako kot naravi in pesniškim stvaritvam so tudi rokodelskim stvaritvam še dopuščali, da so se razkrivale v svojem obstajanju. Novoveški zahodni človek pa s sámim obstajanjem vsega na tem svetu $-\mathrm{s}$ tem torej, da vse na tem svetu preprosto in $\mathrm{v}$ prvi vrsti predvsem je - ni vedel več kaj početi. Če o vsem na tem svetu lahko rečemo - sicer z vso čutno, doživljajsko gotovostjo - le to, da obstaja, da torej je, potem je to najrevnejša, popolnoma 
nedoločena resnica in v svoji nedoločenosti enaka niču, je v svoji Fenomenologiji duha (1807, slovenski prevod 1998) zapisal nemški filozof Georg Wilhelm Friedrich Hegel (1770-1831). Samo golo obstajanje je za Hegla enako niču zato, ker ga ni mogoče misliti. Zanj je izvor in merilo vsega, kar sploh je, le tisto najvišje, kar je mogoče misliti. Večno življenje in vsa resnica je lahko le absolutna ideja. Osupljivo podobno je razmišljal Raskolnikov, glavni junak iz romana Zločin in kazen, ki ga je leta 1866 napisal Fjodor Dostojevski (1821-1881): »Zakaj živeti? Kaj hoteti? K čemu stremeti? Živeti, da bi le bival? Toda on je bil že prej tisočkrat pripravljen darovati svoje bivanje za idejo, za upanje in celo za fantazijo. Bivanje sámo mu je bilo vedno premalo.«(Dostojevski, 2010). Problem izjave je, da je Raskolnikov prav zato, ker je svoje bivanje podredil ideji, postal morilec. Kdor nekoliko bolj pozna ustvarjanje Dostojevskega, ve, da so njegovi romani pravzaprav umetniški »obračuni « $\mathrm{z}$ novoveško zahodno filozofijo, ki ji čudež, da stvari in bitja na tem svetu sploh obstajajo in bivajo, ne pomeni več prav nič. Raskolnikov zato ni čisto navaden morilec, ampak je nekakšna čutna podoba resnice te filozofije, ki jo najbolj nazorno pooseblja predvsem njen utemeljitelj in eden najpomembnejših predstavnikov razsvetljenstva, francoski filozof in matematik René Descartes (1596-1650).

Novoveška filozofija in znanost sta utemeljeni na kratkem stavku, ki ga vsi poznamo, vprašanje pa je, ali se sploh zavedamo, kako globoko je zaznamoval naše dojemanje sveta in naše ravnanje v njem - in z njim. Znameniti stavek, ki ga je Descartes prvič zapisal v svoji Razpravi o metodi pravilnega vodenja razuma v iskanju resnice v naravoslovju (1637, v slovenskem prevodu je prvič izšla leta 1957, drugič leta 2007), se glasi Mislim, torej sem in predstavlja Arhimedovo točko gotovosti, ki jo je novoveški človek »ustvaril« iz tesnobe pred neznanim. Stavek pomeni, da sem, torej obstajam, le, če mislim. Pomeni pa tudi, da za tega novoveškega človeka v svetu - torej »zunaj« njega - obstaja le tisto, kar lahko »otipa « s svojo mislijo. Ali kot je v svoji razpravi Evropski nihilizem, ki jo je mogoče prebrati na spletu, zapisal profesor filozofije na Filozofski fakulteti v Ljubljani Janko Lozar Mrevlje (1973-): »Vse tisto, kar ni predstavljeno v duhu povsem jasno in razločno, enostavno ne biva, je za mislečo stvar nebistveno in s centrifugalno silo dvoma izvrženo v temo nebiti. [...] O bivanju sanjskih, čutnih in oddaljenih stvari je enkrat za vselej padla odločitev: teh stvari ni.«Za Descartesa je, kot vidimo, človekov jaz reduciran na zgolj »mislečo stvar « (latinsko »res cogitans«), ki je od telesa neodvisna, lahko biva tudi brez njega ter pomeni pravzaprav bistvo človeka, vse stvari pa so - kot pravi Heidegger - reducirane na ideje in predstave, katerih resničnost je določena s pravili, ki jih postavlja človek kot misleča stvar. Za Galileja in vso novoveško znanost je tako pravilo matematika: mnogoterost narave tako postane le še matematična mnogoterost, je v Krizi evropskih znanosti (2005) zapisal nemški filozof Edmund Husserl (1859-1938). Ali drugače povedano: od bivanjske moči kipeča in v svoji darežljivi navzočnosti polna narava postaja le matematična abstrakcija, ta matematična abstrakcija pa je zdaj - paradoksno - dejstvo, objektivnost in trdna resnica narave. S Horkheimerjem in Adornom se je mogoče samo strinjati, da to pomeni nekakšno »likvidacijo« konkretne narave. Posebej pa je treba tudi opozoriti, da je matematika le miselno orodje, ne pa mišljenje. Horkheimer in Adorno sta pronicljivo zapisala, da razsvetljenstvo matematiko izenačuje z mišljenjem: mišljenje 
spreminja v stvar in orodje, matematiko pa v absolutno merilo resničnosti. Dopisala pa sta tudi nekaj izredno pomembnega: »Razsvetljenstvo je [tako] potisnilo vstran klasično zahtevo, da velja misliti [tudi] mišljenje [sámo]«. Misel, ki se je bomo spomnili še enkrat.

Zdi se, da zdaj že lahko z večjo zanesljivostjo zapišemo, da Bourdieujevo vrednostno »izenačevanje « Galilejevega razumevanja narave in neoliberalnega pogleda na ekonomijo in družbo morda sploh ni izmišljeno. S tega stališča si velja pozorneje prebrati odlomek iz prispevka Lekcije krize in aktualnost Marxove kritike politične ekonomije, ki ga je v Mladinini posebni številki z naslovom Alternative, zima 2014/15 objavil filozof Samo Tomšič (1979-) in ki govori tudi o neoliberalni ekonomiji:

»Liberalna in neoliberalna ekonomija izhajata iz prepričanja, da kapitalizem gradi na trdnih tleh in da zakoni, ki podpirajo blagovne in finančne trge, niso nič manj nujni in nespremenljivi kot zakoni narave. Kot znanost, podkrepljena s številnimi formalnimi in statističnimi podatki ter tudi s celo vejo matematike in modeliranja, hoče ekonomija analizirati pretekle dogodke, postavljati diagnoze v sedanjosti in predvidevati gibanje finančnih tokov v prihodnje. S tem hoče pokriti vse časovnosti in izključiti morebitna tveganja, nestabilnosti in naključja, ki bi vrgli trg iz njegovega domnevnega ravnovesja. Toda ali je ekonomska vera v nujnost tržnih zakonov res znamenje znanosti? Ali je uporaba abstraktnih matematičnih modelov in statističnih shem [...] res tisto, kar jamči znanstvenost neke panoge? Nedavne kritike [...] so izpostavile, da ekonomska matematika uporablja modeliranje selektivno in kot [...] operacijo, ki v ničemer ne razloži tržnega delovanja, temveč enostavno prikroji realno stanje modelu. Modeli ne opisujejo, kako stvari so, temveč kako morajo biti. Ta obrat v ekonomski vednosti postavlja v ospredje njeno fiktivno naravo, ki ima eno pomembno funkcijo: prekriti in mistificirati strukturne neenakosti, nestabilnosti in protislovja. Hkrati dela iz ekonomije ukazovalno znanost.« (Tomšič, 2014.)

Tomšičev razmislek o neoliberalni ekonomiji nas sili, da zapišemo naslednjo tezo: kot je Raskolnikov čutna podoba resnice novoveške filozofije, ki jo predstavljata Descartes in Hegel, tako je neoliberalizem »podivjani« otrok razsvetljenstva (med Raskolnikovom pred spreobrnitvijo in neoliberalizmom na prvi pogled ni nobene razlike). Tezo - vsaj prvi vtis je tak - potrjuje misel, ki sta jo o razsvetljenstvu zapisala Horkheimer in Adorno (2002): »Razsvetljenstvo je totalitarno. « Do reči se vede »kot diktator do ljudi. Pozna jih, kolikor more z njimi manipulirati. Človek znanosti pozna stvari, kolikor jih izdela sam.«

Ključen za našo trditev, da je neoliberalizem »podivjani« otrok razsvetljenstva, je Horkheimerjev in Adornov stavek: »Človek znanosti pozna stvari, kolikor jih izdela sam.« To je le miselna izostritev tega, kar počne novoveška znanost s konkretno naravo kot predmetom svojega raziskovanja: spreminja jo namreč - kot smo videli - v matematične abstrakcije, ki Horkheimerju in Adornu pomenijo »likvidacijo « konkretne narave. Toda ali niso matematične abstrakcije - znanstveno ugotovljena dejstva o naravi - v bistvu stvaritve, 
ki jih je ustvaril človek novoveške znanosti sam? In - ali niso popolnoma osvobojeni trg, odpravljanje določil, ki preprečujejo kopičenje dobička, umik države iz gospodarstva, privatizacija državnega premoženja ter krčenje javnega sektorja in socialnih pravic kot »neizpodbitna znanstvena dejstva « prav tako stvaritve neoliberalnih ekonomskih znanstvenikov samih? Med obema vrstama znanstvenega početja obstaja razlika, vendar bolj v stopnji obvladovanja narave in ljudi.

Če si sposodimo besednjak Horkheimerjevega in Adornovega stavka, znanstvenik z vso gotovostjo spozna naravo le tako, da jo (iz)meri. (Iz)meri pa jo lahko le zato, ker se novoveškemu človeku narava razkriva kot predmet in se mu kot taka »pusti« meriti. Z merjenjem si je novoveški človek tako rekoč v resnici »izdelal« naravo, si jo »prisvojil« in postal njen gospodar. Zdaj ji lahko - kot si je želel Bacon - »zapoveduje v praksi«, kar pomeni, da jo lahko uporablja v svoje namene. Razvoj tehnike je posledica takega človekovega razmerja do sveta. Kot dokazujejo merjenja bralne, matematične in naravoslovne pismenosti pri učencih v raziskavi PISA (Program mednarodne primerjave dosežkov učencev), povedano ne velja samo za raziskovanje narave.

Danes pa se vse, kar biva, ne razkriva več niti kot predmet. Vse obstaja le, če je na razpolago kateremu koli smotru. Nemški filozof Martin Heidegger (1889-1976) je to bivanjsko spremembo v Vprašanju po tehniki nazorno razložil s primerom tehničnega izdelka:

»Prometno letalo, ki stoji na vzletišču, [...] je neki predmet. Gotovo. Ta stroj lahko tako predstavimo. Skrije pa se tedaj kot tisto, kar je in kakor je. Razkrit stoji na vzletišču samó kot razpoložljiv obstanek, kolikor je postavljen na razpolago za zagotovitev možnosti transporta. $\mathrm{V}$ ta namen mora biti ves, $\mathrm{v}$ vsej svoji zgradbi, v vsakem svojem sestavnem delu, postavljen kot razpoložljiv, to je pripravljen na start.« (Heidegger, 2003.)

V tem smislu je letalo »kratko malo nesamostojno«, je samo toliko, kolikor opravlja svojo vlogo - tako kot je danes človek le še »delovna sila«, »človeški vir«, »statistični vzorec«, »volilno telo«. Ta bivanjska sprememba je povzročila, da se je spremenila tudi vloga znanosti. Znanost je zdaj postala tehnoznanost. Neoliberalna ekonomska znanost je zgled tehnoznanosti: njena edina vloga je, da z znanstvenimi metodami podpre ideologijo popolnoma svobodnega trga, misli pa je več ne. Znanstveno mišljenje - pa ne samo znanstveno - je tako postalo le še instrumentalno, »tehnično « opravilo. Martin Heidegger je v svoji kratki razpravi Sproščenost, ki je izšla leta 1959, to mišljenje poimenoval računajoče mišljenje. Opisal ga je takole: »Računajoče mišljenje je mišljenje, ki načrtuje in raziskuje. Tako mišljenje ostaja računanje tudi, če ne dela s števili in ne uporablja računalnika. Računajoče mišljenje računa. Preračunava vedno nove, bolj obetavne in hkrati boljše ekonomske možnosti.« Računajoče mišljenje za Heideggerja sploh ni mišljenje. Zanj je mišljenje, ki zasluži, da se tako imenuje, le premišljajoče mišljenje. Le tako mišljenje lahko premišljuje o smislu, ki vlada v vsem, kar obstaja. Za Heideggerja je premišljajoče mišljenje človekovo bistvo: »Človek je misleče, to pomeni, premišljajoče bitje.«Heideggerjeva največja bojazen je bila, da bi računajoče 
mišljenje nekoč postalo edino človekovo »mišljenje« (Heidegger, 1959). To nevarnost je mogoče odvrniti le z vztrajnim premišljajočim mišljenjem, mišljenjem, ki bo človeku zopet »odprlo oči« za darežljivo skrivnostnost obstajanja vsega živega in neživega na tem svetu in mu omogočilo, da sestopi s prestola Gospodarja sveta. ${ }^{3}$

\section{UNIVERZE SE BODO RESNIČNO DEMOKRATIZIRALE ŠELE TEDAJ, KO JIH BODO PRIHODNJE GENERACIJE ZAPUSTILE}

Izobraževanje je danes na vseh svojih ravneh v krizi. Tudi na univerzi ga razumejo vedno bolj kot tehnokratsko »vlivanje« znanja v »glave« študentov, ki so tako postali le še trpni predmet izobraževalnega pogona. V tako razumljenem izobraževanju ni »blago« le znanje, ampak so »blago« postali tudi učitelji in študenti. Ali kot je »slikovito« zapisano v knjigi s presunljivim naslovom Ubijanje mišljenja. Smrt univerz (Killing Thinking. The Death of the Universities), ki jo je leta 2004 napisala angleška univerzitetna profesorica ženskih študij Mary Evans: profesorji so (tudi) v Veliki Britaniji postali samo še avtomati, ki študentom »dobavljajo učno blago«, študenti, ki so tudi postali avtomati, pa ga samo še »dvigujejo«. Študijskih programov na naših univerzah na primer ne izvajajo več le tisti učitelji, ki so jih zasnovali, ampak to lahko počnejo tudi tisti, ki pri snovanju sploh niso sodelovali, od števila študentov je do nedavna bilo odvisno celo financiranje posameznih fakultet, vedno glasnejša so tudi razmišljanja o plačljivosti študija. Da ne omenjamo vsaj že desetletje trajajočih neoliberalnih »zahtev« po podrejanju univerze gospodarstvu in »trgu dela«, kar bolonjska prenova univerze na svoj način bolj ali manj »vestno« tudi že uresničuje. Taka usmeritev pa ni postala uradni cilj samo univerzitetnega, ampak vsega izobraževanja v Evropski uniji. Brati moramo samo strateški dokument Evropske komisije z naslovom Premislek o izobraževanju: investicija v spretnosti za boljše socialno-ekonomske dosežke (2012). V njem najdemo zapisan tudi naslednji stavek: »[E]vropski [izobraževalni] sistemi še vedno ne zagotavljajo pravih spretnosti za zaposljivost in ne sodelujejo ustrezno s poslovnim okoljem in zaposlovalci, da bi približali učno izkušnjo realnosti delovnega okolja.«Prav to neskladje med potrebami gospodarstva in kompetencami, ki jih ponuja šola, naj bi povečevalo »skrb za kompetitivnost evropske industrije« (več je mogoče prebrati v spremni študiji Slavka Gabra v drobni knjižici Finska v vrhu znanja 2030. Študija o prihodnosti izobraževanja. Poročilo finskega sindikata vzgoje in izobraževanja OAJ, ki je v slovenskem jeziku izšla leta 2014). Neoliberalna ideologija tako postaja idejni temelj vsega sodobnega izobraževanja.

Táko izobraževalno politiko je v svoji knjigi z naslovom Dobro izobraževanje v dobi merjenja (Good Education in an Age of Measurement, 2010) nizozemski univerzitetni profesor in raziskovalec na področju izobraževanja Gert J. J. Biesta (1957-) ostro kritiziral: »Izobraževanje postane neizobraževalno, če vso svojo pozornost usmeri le v socializacijo - to je v 'nameščanje' 'prišlekov' v obstoječi družbeni, kulturni in politični red [ki je danes neoliberalen, saj ga določa, kot vidimo, predvsem, če ne celo izključno, ekonomija; opomba je moja] - in ne kaže zanimanja za načine, na katere lahko prišleki nekako hkrati

3 Besedilo je kot uvodnik izšlo v mesečniku za poljudno naravoslovje Proteus (2014, letnik 77, številka 3). 
postajajo tudi neodvisni od takega reda. Z drugimi besedami, izobraževanje mora vedno namenjati posebno pozornost tudi človekovi svobodi [...]« (Biesta, 2010).

V Biestovi kritiki sodobne neoliberalne izobraževalne politike odmeva misel, ki jo je nemški filozof Immanuel Kant (1724-1804) zapisal v svojem znamenitem besedilu Odgovor na vprašanje: Kaj je razsvetljenstvo? (1783, v slovenskem prevodu leta 1987 in leta $2006 \mathrm{v}$ knjigi Immanuel Kant: Zgodovinsko-politični spisi): »[J]avna uporaba lastnega uma mora biti vsekakor svobodna in samo ona lahko pripelje do razsvetljenosti med ljudmi. Njegova zasebna raba je lahko pogosto tudi zelo omejena, ne da bi bil zato napredek v razsvetljevanju huje prizadet. $\mathrm{Z}$ javno rabo lastnega uma razumem tisto, ki jo kdo kot učenjak izvaja pred celotnim občinstvom sveta bralcev. Zasebno rabo uma pa imenujem tisto, ki si jo sme dovoliti na določenem zaupanem mu civilnem položaju ali uradni službi.« (Kant, 2006).

Če Biestovo kritiko povežemo s Kantovo razsvetljensko mislijo, potem lahko zapišemo naslednje. Kadar učitelji »izobražujejo« le zato, da bi se otroci, učenci in študenti čim bolj »uspešno « poistovetili z »obstoječim družbenim, kulturnim in političnim redom « - ki je danes neoliberalen -, se predajajo zasebni rabi uma. Z drugimi besedami, delujejo kot »nedoletni« posamezniki, kot tisti torej, ki niso sposobni »uporabljati svojega razuma brez vodstva koga drugega«. Biesta ima popolnoma prav: tako izobraževanje v resnici sploh ni izobraževanje, je samo učenje, neredko celo zgolj urjenje spretnosti »za boljše socialno-ekonomske dosežke«. Posledica takega »izobraževanja« - ki pa je hkrati tudi vzrok zanj - je »nedoletna«, neoliberalna avtoritarna družba.

Današnjo prevladujočo neoliberalno avtoritarno družbo obvladuje torej - če uporabimo besednjak Slavoja Žižka iz besedila Leninova izbira (2010) - nekakšen nezapisani Denkverbot, »prepoved « mišljenja, ki jo zgodovinsko ponazarja znamenita izjava angleške ministrske predsednice Margaret Thatcher: »Neoliberalizem nima alternative.« Sporočilo ljudem je »jasno«: Ne razmišljajte, neoliberalno upravljanje gospodarstva je »naravno« dejstvo, vse drugo so le fantazije, zato bodite poslušni in »vam bo dobro na zemlji«. Biesta je prepričan, da bi se učitelji - kot tudi vsi ljudje - morali odločno spopasti z neoliberalno »prepovedjo« mišljenja in se osvoboditi uročenosti z njo. To pa lahko storijo le, če začnejo izobraževati v skladu s Kantovim razsvetljenskim geslom: »Bodi pogumen, uporabljaj svoj lastni razum.« Tako uporabo razuma je Kant imenoval javna raba uma. Opisal jo je takole:

»Za razsvetljenstvo pa ni treba drugega kot svobode in to najbolj neškodljive od vsega, kar se lahko imenuje svoboda, namreč tole: uveljavitev vsestranske javne rabe lastnega uma. Zdaj pa slišim z vseh strani klice: ne rezonirajte [poslovenjeno: ne razmišljajte]! Častnik pravi: 'Ne rezonirajte, eksercirajte!' Finančni svetnik: 'Ne rezonirajte, plačajte!' Duhovnik: 'Ne rezonirajte, verujte!' [...] Vsepovsod je tu omejitev svobode. Katera omejitev pa je razsvetljenstvu v oviro in katera to ni, temveč ji je le v pomoč? - Odgovarjam: javna raba lastnega uma mora biti vsekakor svobodna in samo ona lahko pripelje do razsvetljenosti med ljudmi.« (Kant, 2006.) 
Zdaj se lahko vrnemo k drugemu delu Biestovega besedila. V njem je zapisano Biestovo razumevanje javne rabe uma $\mathrm{v}$ izobraževanju. Izobraževanje je táko lahko le takrat, kadar $\mathrm{v}$ otrocih, učencih in študentih razvija sposobnost in moč za kritično spoprijemanje z obstoječim družbenim, kulturnim in političnim redom, ki je danes neoliberalen. Kar pa ni dovolj. V otrocih, učencih in študentih mora namreč razvijati tudi sposobnost in moč za kritično spoprijemanje s samim seboj. Izobraževanje mora zato vedno namenjati posebno pozornost tudi človekovi svobodi.

Biesta izobraževanje očitno razume kot Bildung (ta nemški klasični humanistični pojem je zaradi svoje pomenske mnogoznačnosti izredno težko prevesti z eno besedo, v slovenščini zanj uporabljamo celo vrsto izrazov: izobrazba, kultura, omika, vzgoja, samoporajanje). Nemški filozof Hans-Georg Gadamer (1900-2002) je v knjigi Resnica in metoda (1960, v slovenskem prevodu 2001) pojmu Bildung podelil prav poseben pomen, z njim je kot cilj mišljenja izpodrinil in nadomestil pojem »vednosti«. Trdil namreč je, da je preoblikovanje nas samih najpomembnejše, kar lahko storimo v življenju. Skrajno subtilni pojem Bildung zaznamuje torej človekovo bivanjsko naravnanost, ki jo dovolj dobro opisuje tudi beseda samoporajanje. Gadamerju samoporajanje pomeni, da človek postaja novo bitje. Kaj pa sploh pomeni postajati novo bitje? Stališče nemškega filozofa Georga Wilhelma Friedricha Hegla (1770-1831) je bilo naslednje: Obče bistvo človeške omike je, da iz sebe naredi obče duhovno bitje. Kdor se prepušča partikularnosti, kdor se žene samo za svojimi zasebnimi koristmi, kdor se - če uporabimo Kantov besednjak - predaja zasebni rabi uma, je zato neomikan. Toda Hegel ne bi bil Hegel, če ne bi dodal: Bistvo vsakega človekovega delovanja je, da snovno in družbeno resničnost omikuje, namesto da bi jo potrošilo, »uničilo«. Ko pa človek omikuje snovno in družbeno resničnost, omikuje in spoznava tudi samega sebe. Omika, Bildung, tako pomeni etično bivanjsko držo, ki si prizadeva za dostojanstvo vsega živega in neživega.

Zdaj je morda bolj razumljivo, zakaj je Biesta pri svojem razmišljanju o dobrem izobraževanju uporabil pojem pedagogika prekinitve, lahko bi rekli tudi pedagogika osvoboditve. V človeku skuša odkriti in razviti sposobnosti in moč, da bi se lahko »iztrgal « iz dušečih vezi obstoječega družbenega, kulturnega in političnega reda ter njegovih ustanov in da jih ne bi več jemal za nekaj samoumevnega in nespremenljivega. Pedagogika osvoboditve skuša omogočiti porajanje »novega človeka« in »nove družbe«.

Boj Mary Evans za »prenovitev« univerz v obdobju neoliberalizma je paradoksen. Razumemo ga lahko kot alegorijo vsega povedanega $v$ tem eseju:

»Naslov knjige namiguje na možnost smrti v slonokoščenem stolpu univerze. [...] Obstaja verjetnost, da se bodo stolpi počasi začeli prazniti z ustvarjalnostjo, ko se bodo nove generacije naveličale smrtonosnih možnosti birokratizirane univerze in se odločile, da zapustijo njen svet in začnejo razvijati svojo nadarjenost kje drugje. Če se bo to zgodilo, bodo univerze, kakršne smo poznali do sedaj, verjetno počasi izginile. Morda se bodo univerze resnično demokratizirale šele tedaj, ko jih bodo prihodnje generacije zapustile; morda 
ni več potrebno, da ideje živijo v posebej za njih namenjenih prostorih. [...] Če naj izobraževanje v liberalni demokraciji sploh kaj pomeni, potem moramo priznati, da ni nujno, da ga izenačujemo s prilagodljivostjo in poslušnostjo ter kaznovalnimi režimi ocenjevanja dosežkov. Morda bi na začetku 21. stoletja spet morali poskusiti uživati v pristni akademski svobodi.«(Evans, 2004.)

Nekaj podobnega trdi tudi »avtorska skupina« slovenskih študentov, raziskovalcev in univerzitetnih učiteljev v knjigi z naslovom Kaj po univerzi? Izšla je leta 2013.

In - ali ni že Albert Einstein svoja velika odkritja objavljal, ko je služboval na patentnem uradu in ne na univerzi? ${ }^{4}$

\section{LITERATURA}

Arendt, H. (2007). Eichmann v Jeruzalemu: banalnost zla. Ljubljana: Študentska založba.

Bacon, F. (1592). The Praise of Knowledge. Pridobljeno s http://nzetc.victoria.ac.nz//tm/scholarly/tei-Stout04-t4-body-d2-d61.html.

Bauer, J. (2008). Princip človeškosti. Ljubljana: Študentska založba.

Benjamin, W. (1996). Selected Writings, Volume 1. Cambridge: Belknap Press of Harvard University Press. Berardi - Bifo, F. (2013). Duša na delu. Ljubljana: Maska, 2013.

Biesta, G. (2010). Good Education in an Age of Measurement. Boulder: Paradigm Publishers.

Bourdieu, P. (1998). Acts of Resistance. Against the Tyranny of the Market. Pridobljeno s http://www. opaa2a.org/dissensus/wpcontent/uploads/2008/02/BOURDIEU_Pierre_Acts_of_Resistance_Against_the_Tyranny_of_the_Market94-108.pdf.

Dawkins, R. (2006). Sebični gen. Ljubljana: Mladinska knjiga.

Descartes, R. (2007). Razprava o metodi pravilnega vodenja razuma $v$ iskanju resnice v naravoslovju. Ljubljana: Založba ZRC SAZU.

Dostojevski, F. (2010). Zločin in kazen. Ljubljana: DZS.

Evans, M. (2004). Killing Thinking. The Death of the Universities. London: Continuum.

Freitag, M. (2010). Brodolom univerze in drugi eseji iz politične epistemologije. Ljubljana: Sophia.

Gaber, S. (2014). Finska v vrhu znanja 2030. Ljubljana: Center za študij edukacijskih strategij - CEPS, Pedagoška fakulteta.

Gadamer, H. G. (2001). Resnica in metoda. Ljubljana: Literarno-umetniško društvo Literatura.

George, S. (2013). Obstaja na tisoče alternativ. Pridobljeno s http://www.delo.si/zgodbe/sobotnapriloga/ obstaja-na-tisoce-alternativ.html.

Gunder Frank. A. (1974). Economic Genocide in Chile. Monetarist Theory Versus Humanity. Two Open Letters to Arnold Harberger and Milton Friedman. Pridobljeno s http://www.rrojasdatabank.info/ genoc1a.pdf.

Hegel, F. G. W. (1998). Fenomenologija duha. Ljubljana: Društvo za teoretsko psihoanalizo.

Heidegger, M. (1959). Discourse on Thinking. Pridobljeno s http://isites.harvard.edu/fs/docs/icb.topic 1308144.files/February\%203/Heidegger\%20-\%20Memorial\%20Address.pdf.

Heidegger, M. (2003). Vprašanje po tehniki. V M. Heidegger, Predavanja in sestavki. Ljubljana: Slovenska matica.

4 Malce spremenjeno besedilo je kot uvodnik izšlo v mesečniku za poljudno naravoslovje Proteus (2014, letnik 77, številka 4). 
Higgs, P. (2013). Peter Higgs interview: »I have this kind of underlying incompetence«. Pridobljeno s http://www.theguardian.com/uk.

Holloway, J. (2002). Spreminjajmo svet brez boja za oblast. Pridobljeno s http://www2.arnes.si/ ljiek3/ Holloway/holloway.pdf.

Horkheimer, M., Adorno, T. (2002). Dialektika razsvetljenstva. Ljubljana: Studia humanitatis.

Husserl, E. (2005). Kriza evropskih znanosti in transcendentalna fenomenologija. Ljubljana: Slovenska matica.

Jelić, M. (2014). Pašukanis: »Opšta teorija prava i marksizam«. Pridobljeno s http://www.marks21.info/ recenzija-knjige/j-b-pasukanis-opsta-teorija-prava-i-marksizam.

Kaj po univerzi (2013). Ljubljana: Založba /*cf.

Kant, I. (2006). Zgodovinsko-politični spisi. Ljubljana: Založba ZRC SAZU.

Kocbek, E. (1963). Groza. Ljubljana: Slovenska matica, 1963.

Kocbek, E. (1974). Misli o jeziku. V E. Kocbek, Svoboda in nujnost (str. 205-221). Celje: Mohorjeva družba.

Košak, K. (2014). Krivdo nosim sam. O spornosti koncepta »podjetnosti« v izobraževanju. Pridobljeno s http://www.mladina.si/160141/krivdo-nosim-sam/.

Krašovec, P. (2013). Teorija in praksa levice po levici. V P. Mattick, Vse po starem: gospodarska kriza in polom kapitalizma. Ljubljana: Studia humanitatis.

Mattei, U. (2011). The State, the Market, and some Preliminary Question about the Commons. Pridobljeno s http://works.bepress.com/ugo_mattei/40.

Mattick, P. (2013). Vse po starem: gospodarska kriza in polom kapitalizma. Ljubljana: Studia humanitatis.

Mlakar, P. (2014). Ali podjetništvo sodi v splošne šole? Pridobljeno s http://www.dnevnik.si/slovenija/ ali-podjetnistvo-sodi-v-splosne-sole.

Nobelprize (2004). The Nobel Prize in Literature. Elfriede Jelinek. Pridobljeno s http://www.nobelprize. org/nobel_prizes/literature/laureates/2004/.

Odločba Ustavnega sodišča o neustavnosti določb Zakona o visokem šolstvu in Uredbe o javnem financiranju visokošolskih in drugih zavodov (U-I-156/08 z dne 14.4.2011). V Zakon o visokem šolstvu (ZVIS-)1, Osnutek (2013, 2014).

Pašukanis, E. (2014). Splošna teorija prava in marksizem. Ljubljana: Sophia.

Premislek o izobraževanju: investicija v spretnosti za boljše socialno-ekonomske dosežke (2012). Strasbourg: Evropska komisija. Pridobljeno s http://www.europarl.europa.eu/meetdocs/2009_2014/ documents/com/com_com(2012)0669_/com_com(2012)0669_sl.pdf.

Schekman, R. (2013). How journals like Nature, Cell and Science are damaging science. Pridobljeno s http://www.theguardian.com/uk.

Tomšič, S. (2014). Lekcije krize in aktualnost Marxove kritike politične ekonomije. Mladina - Alternative, 2014/15. Pridobljeno s http://www.mladina.si/162431/lekcije-krize-in-aktualnost-marxovekritike-politicne-ekonomije/.

Zakon o visokem šolstvu, osnutek (2014). Pridobljeno s http://www.mizs.gov.si/fileadmin/mizs.gov.si/ pageuploads/Visoko_solstvo/ZViS_2015/ZViS_koncept_1622015.pdf.

Žižek, S. (2010). Leninova izbira. V S. Žižek, Začeti od začetka. Ljubljana: Cankarjeva založba.

Žižek, S. (2014). Language, Violence and Non-Violence. Pridobljeno s www.zizekstudies.org/index.php/ ijzs/article/download/154/240. 